other way, by requiring its own departments to buy British (which means ICL) when purchasing any computer with more than a specified amount of computer power.

One result of this lack of support is to induce British companies to adopt an "if you can't beat them, join them" policy. ICL has joined in a three-sided agreement with two American companies, NCR and Control Data Corporation, covering the development and manufacturer of peripherals. Data
Recording Instrument Company has similarly made agreements with various North American companies concerning the supply and manufacture of disk drives.

It is depressing to move into 1976 without any sign of a change of attitude from the British government. Certainly none could be detected in the speech made by Eric Varley, Secretary of State for Industry, at the opening this month of the National Computing Centre's new headquarters. Still, it could be worse. One of the saddest events of 1975 was the collapse of Unidata, a pan-European computer manufacturer formed from the French government company Compagnie Internationale pour l'Informatique, and from the computer subsidiaries of Philips of Holland and Siemens of Germany. ICL was at one stage under considerable pressure to join this triumvirate, but resisted, and consequently remains alive and well-and profitable.
When the Loch Ness Monster osten- attempt was made to identify the obsibly raised its ugly head (see picture) jects shown. That, said Dr Rines, was with the support of Sir Peter Scott, for qualified biologists to do-not himwidespread public interest was in- self.

evitable. What was far less certain was the reaction of the scientific community. As it turns out, Scott and his colleague Robert Rines must be reasonably content.

Their original plan was to present at a two-day scientific symposium the full evidence which they felt supported the existence of large animals in Loch Ness. The outcome, they hoped, would at least allow the existence of the animal to be given the benefit of the doubt. They also wanted it officially named in order to have it legally protected as an endangered species. An attack of cold feet gripped the organisers of the symposium, however, and they withdrew their support.

The only forum left for the presentation of evidence was a meeting in the Grand Committee room at the House of Commons-a room, some would say, that is steeped in the history of monstrous debate. It was held on the evening of December 11 before representatives of the public, the press, and the scientific community, along with Members of Parliament understandably seeking relief from the second reading of the Armed Forces Bill, which was making $\mathrm{Mr}$ Wellbeloved less endearing then Nessie.

The bulk of the meeting was devoted to presentations by members and associates of the Academy of Applied Science-a 'non-profit, scientific and educational corporation' lodged at the Boston home of its president, Robert Rines. The academy has been investigating Loch Ness every summer for the past five years.

The optical and sonar systems used and the site chosen for the attempt to obtain underwater photographs of the monster were both presented in dazzling detail. Much was then made of the 1972 photographs which, after computer enhancement, showed 'flipper-like objects'. But when it came to the expected climax of the 1975 photographs, Rines' presentation was so modest that he nearly blushed. No
Three biologists handily placed on the platform then stated their beliefs that the photographs contained various images suggestive of flippers, a body

\section{Nessiteras skeptyx}



and a head, all of which indicated the presence of large animals in Loch Ness. In that they were further supported by a statement from Professor A. W. Crompton of Harvard. None of the biologists, however, was prepared to try to identify the animal.

The discussion period that closed the meeting provided few fireworks. Most of the questions were on a scientist-toscientist basis; they ranged from the be air-breathing to queries about size controls for the objects photographed. Critical comments attained various levels. Hugh Fraser MP said that judging by his disappointing fishing experience in Loch Ness, the salmon in the evening was a gross exaggeration. He did not profer an alternative explanation of his performance, relating to the likely appetites of any animals in the Loch. David Attenborough suggested that the 1972 flipper-like obiects might actually be the fin of a fish. And that, it seemed, problem of whether the animal would population of 13 million claimed earlier was the cue for the heavy artillery from the British Museum to open fire. Dr Gordon Sheals supported the view that the flippers were fish fins, and that their estimated size was "wildly" miscalculated. When that was disputed and further claims were made for the presence of a large animal, he decided it was time to broaden the attack. There was, he said, no evidence to support the view that the same object was shown in each photograph, nor to suggest that any of them showed a living object. Furthermoreand this was the body blow-it was most regrettable that Nature had published the article by Scott and Rines.

Another sceptic from the British Museum, Dr Humphrey Greenwood, conceded what several more sympathetic voices had already suggestedthat there was a sufficient case for the evidence now to be published in full detail so that it could be properly scrutinised. The delighted $\mathrm{Dr}$ Rines clearly felt the battle was half won. $\mathrm{He}$ was at least being taken seriously.

Less serious was the response of the mass media. By and large the photographs were presented with a healthy dose of scepticism to accompany them and some astonishing artist's impressions of what they showed. The more enterprising journalists managed to winkle out people with something they thought approached a knowledgeable view. Unsurprisingly, the claims were as diverse as they were knowledgeable. One view was that the photographs actually showed parts of a Viking ship. Another, on television, was that the "head" was of a scuba diver wearing his breathing apparatus back to front. The grateful monster-following public also learned that the British Bacon Curers' Federation was to organise a hunt for Nessie by hot air balloon.

If the eventual truth of the monsterhunters' claims is still breathlessly awaited, at least they, though perhaps not their prey, have finally come in from the cold. That may be the epitaph on this episode. In the next one, the natural history of L.och Ness may even become a respectable line of study. 